\title{
Isolated brachial artery aneurysm successfully treated with a covered stent in a patient with Behçet's disease
}

\author{
Behçet hastalığı olan bir olguda kaplı stent ile tedavi edilen izole brakiyal arter anevrizması
}

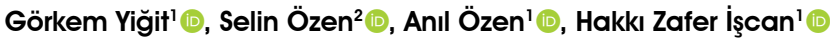 \\ Institution where the research was done: \\ Türkiye Yüksek intisas Training and Research Hospital, Ankara, Turkey
}

Author Affiliations:

'Department of Cardiovascular Surgery, Türkiye Yüksek intisas Training and Research Hospital, Ankara, Turkey

2Department of Physical Therapy and Rehabilitation, Başkent University Faculty of Medicine, Ankara, Turkey

\begin{abstract}
Behçet's disease is a vasculitic pathology characterized by skin lesions, genital ulcers, aphthous stomatitis, and uveitis. Arterial aneurysms are rare in this disease. Herein, we report a rare case of an isolated brachial artery aneurysm with a history of Behçet's disease treated with endovascular covered stenting of the brachial artery.
\end{abstract}

Keywords: Aneurysm, Behçet's disease, brachial artery.

Behçet's disease (BD) is characterized by recurrent aphthous stomatitis, uveitis, genital ulcers, and skin lesions. Since vascular manifestations are common in this disease, it is considered a vasculitis. ${ }^{[1]}$ Vascular involvement affecting vessels of any size has been reported in 7.7 to $38 \%$ of patients with BD. ${ }^{[2]}$ However, arterial aneurysms are rarely seen in BD and account for 10 to $15 \%$ of all vascular complications. ${ }^{[3,4]}$

The traditional treatment of aneurysms in BD patients is open surgery; however, stent-graft placement has become an alternative option in recent years ${ }^{[5]}$ Herein, we report a rare case of an isolated brachial artery aneurysm with a history of BD treated with endovascular covered stenting of the brachial artery.

\section{$\ddot{O} Z$}

Behçet hastalı̆̆ı cilt lezyonları, genital ülserler, aftöz stomatit ve üveit ile karakterize vaskülitik bir patolojidir. Bu hastalıkta arteriyel anevrizmalar nadirdir. Bu yazıda, brakiyal arterin endovasküler kaplı stentlenmesi ile tedavi edilen Behçet hastalığı öyküsü olan nadir bir izole brakiyal arter anevrizma olgusu bildirildi.

Anahtar sözcükler: Anevrizma, Behçet hastalı̆̆ı, brakiyal arter.

\section{CASE REPORT}

A 31-year-old female patient was admitted to our hospital with a pulsatile mass in the right axilla and pain and numbness in the ipsilateral upper extremity without any weakness of the arm. Her medical history revealed $\mathrm{BD}$ which was diagnosed at the age of 10. Her family history was unremarkable. Physical examination revealed a $3-\mathrm{cm}$ pulsatile mass in the right axilla. The mass was round-shaped and smooth, firm, non-tender, and pulsatile. There were no peripheral pulsations in the right brachial, radial, and ulnar arteries. Capillary refill time was normal, and the right hand and arm were at normal body temperature. Neurological examination of the right upper extremity revealed a slight weakness in gross

Received: January 20, 2019 Accepted: May 07, 2019 Published online: October 23, 2019

Correspondence: Görkem Yiğit, MD. Türkiye Yüksek Ihtisas Eğitim ve Araşııma Hastanesi, Kalp ve Damar Cerrahisi Kliniği, 06230 Alıındağ, Ankara, Turkey. Tel: +90 506-677 7577 e-mail: drgorkemyigit@gmail.com 

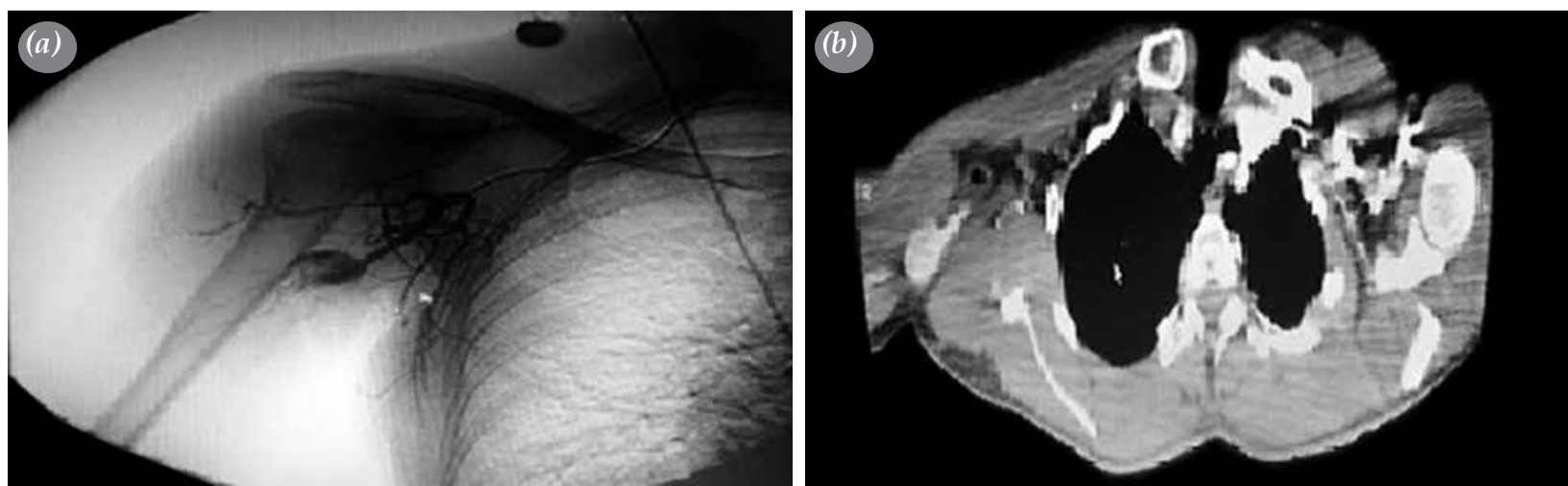

Figure 1. (a) Angiographic image of the axillary artery aneurysm. (b) Computed tomography image of the axillary artery aneurysm.

motor function with sensory loss in the distal phalanx of the right index finger. Examination of the other systems were normal. Routine laboratory testing and chest X-ray results were also normal.

Based on the examination of a physical medicine and rehabilitation specialist, BD was quiescent and no contraindications to vascular intervention were identified. Duplex ultrasound revealed absent blood flow in the radial, ulnar, and brachial arteries. Upper extremity angiograpgy and computed tomography (CT) angiogram revealed an aneurysm of the right axillary artery which was $26 \mathrm{~mm}$ in length and $16 \mathrm{~mm}$ in width (Figure 1a, b). Following femoral artery catheterization, $5 \times 40 \mathrm{~mm}$ balloon dilatation was performed, and two covered stents were placed in the proximal region of the brachial artery (Figures 2 and 3 ). Both radial and ulnar pulses were palpable prior to discharge.

\section{DISCUSSION}

The arterial lesions of BD can affect all types of arteries. However, arterial complications account

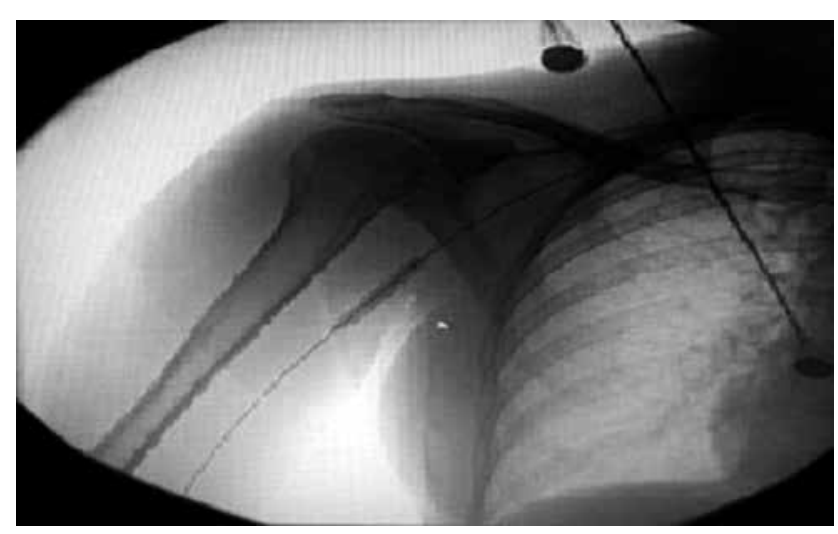

Figure 2. Balloon dilatation of the brachial artery. for only 10 to $15 \%$ of all vascular complications. ${ }^{[4]}$ Indeed, the prevalence of arterial involvement in BD has been estimated at 2.2 to $18 \%$ with a marked male predominance. ${ }^{[6]}$ The most commonly affected artery is the abdominal aorta and pulmonary artery, while the involvement of other arteries is rare. ${ }^{[7]}$

Isolated aneurysm of the brachial artery in BD has been scarcely reported in the literature with only a couple of cases published in 1988 and 1993. ${ }^{[8,9]}$ Koksoy et al. ${ }^{[6]}$ operated 29 aneurysms in BD patients. In their series, all aneurysms appeared to be pseudo-aneurysms. Iscan et al. ${ }^{[10]}$ performed 34 operations in $20 \mathrm{BD}$ patients. Seventeen were emergency procedures, six of which were ruptured primary abdominal aneurysms. Although there were five peripheral arterial aneurysms in their series, none were isolated brachial artery aneurysms. Furthermore, to the best of our knowledge, there are no cases of isolated brachial artery aneurysm in BD treated with endovascular repair in the literature.

The management of any aneurysm is dependent on its size, location, and pathogenesis. Indications for open surgery include rapidly expanding aneurysms, distal ischemia, and neuropathy caused by local pressure.

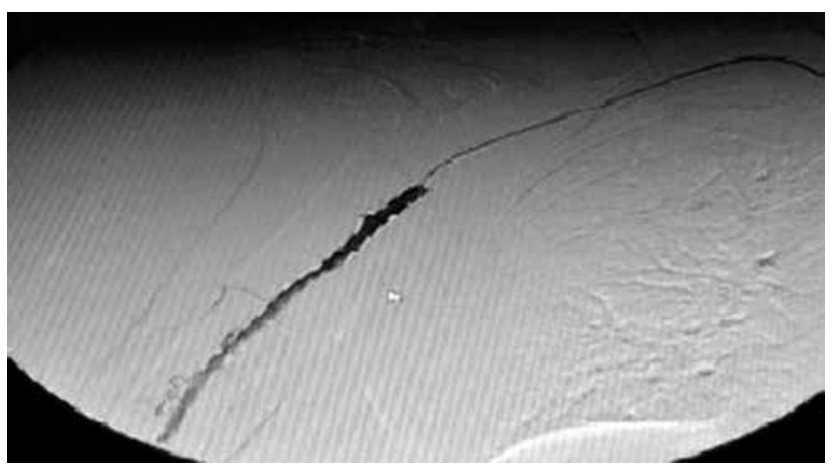

Figure 3. Covered stent placed into the brachial artery. 
Surgical repair in the axillary and brachial area may be associated with several complications, such as major blood loss and potential damage of neurovascular structures. ${ }^{[11,12]}$ In addition, complications of a surgical approach adopted in the active inflammatory phase include suture line dehiscence, pseudoaneurysm formation, graft occlusion, and thromboembolic events. On the other hand, endovascular treatment of BD aneurysms has been increasingly performed in recent years with high technical success rates and low procedure-related complication rates, compared to traditional surgical intervention. ${ }^{[13,14]}$ The effectiveness of endovascular stent grafting of aneurysms in BD was investigated by Watanabe et al. $^{[4]}$ They also demonstrated that using a stent graft may represent a valid alternative to open surgery due to the high aneurysm recurrence rate after surgery. We decided to avoid surgery in our patient, since the aneurysm was not rapidly expanding and the patient did not have signs of ischemia distal to the aneurysm. The decision for endovascular stenting was made to prevent future complications of surgery in such a young patient.

In the past, poor surgical results of arterial aneurysms in BD led to an increasing use of endovascular interventions in recent years. Endovascular treatment is currently considered an effective and safe procedure with acceptable vascular complication rates. ${ }^{[15]}$

In conclusion, as shown in our case, brachial artery aneurysms which are rarely seen in Behçet's disease patients can be also successfully treated with endovascular repair, thereby, avoiding complications of surgery.

\section{Declaration of conflicting interests}

The authors declared no conflicts of interest with respect to the authorship and/or publication of this article.

\section{Funding}

The authors received no financial support for the research and/or authorship of this article.

\section{REFERENCES}

1. Ozguler Y, Hatemi G, Yazici H. Management of Behçet's syndrome. Curr Opin Rheumatol 2014;26:285-91.
2. Lie JT. Vascular involvement in Behçet's disease: arterial and venous and vessels of all sizes. J Rheumatol 1992;19:341-3.

3. Li S, Chen AJ, Huang K, Li H. Successful treatment of vasculo-Behcet's disease presenting as recurrent pseudoaneurysms: the importance of medical treatment. Dermatol Ther (Heidelb) 2013;3:107-12.

4. Watanabe H, Oda H, Yoshida T, Yamaura M, Takahashi $\mathrm{K}$, Miida T, et al. Endovascular stent-grafting for recurrent aneurysm in Behcet's disease. Int Heart $\mathbf{J}$ 2000;46:745-9.

5. Park JH, Chung JW, Joh JH, Song SY, Shin SJ, Chung $\mathrm{KS}$, et al. Aortic and arterial aneurysms in behçet disease: management with stent-grafts--initial experience. Radiology 2001;220:745-50.

6. Koksoy C, Gyedu A, Alacayir I, Bengisun U, Uncu H, Anadol E. Surgical treatment of peripheral aneurysms in patients with Behcet's disease Eur J Vasc Endovasc Surg 2011;42:525-30.

7. Calamia KT, Schirmer M, Melikoglu M. Major vessel involvement in Behçet's disease: an update. Curr Opin Rheumatol 2011;23:24-31.

8. Robbs JV, Naidoo KS. Nerve compression injuries due to traumatic false aneurysm. Ann Surg 1984;200:80-2.

9. Kemp K, Radwan R, Shingler G, Davies C. Brachial artery pseudoaneurysm. BMJ Case Rep 2014;2014.

10. Iscan ZH, Vural KM, Bayazit M. Compelling nature of arterial manifestations in Behcet disease. J Vasc Surg 2005;41:53-8.

11. Kristen R, Schmitz-Rixen T, Huber P, Erasmi H. Aneurysm of the brachial artery--a rare complication of Behçet disease. Case report. Vasa 1988;17:229-32. [Abstract]

12. Aggarwal A, Dabadghao S, Roy S, Agarwal S, Misra R. Brachial artery aneurysm and peripheral gangrene in a patient with Behçet disease. Clin Exp Rheumatol 1993;11:579-80.

13. Kim WH, Choi D, Kim JS, Ko YG, Jang Y, Shim WH. Effectiveness and safety of endovascular aneurysm treatment in patients with vasculo-Behçet disease. J Endovasc Ther 2009;16:631-6.

14. Ding ZY, Jin GN, Ai X, Li LY, Zheng P, Guan Y, et al. Endovascular treatment of behcet disease with recurrent infrainguinal arterial pseudoaneurysms: a case report and literature review. Medicine (Baltimore) 2016;95:e3545.

15. Park S, Lee GH, Park JH, Park BS, Jin K, Kim YW. Successfully treated isolated renal artery pseudoaneurysm in a patient with Behçet's disease. Kidney Res Clin Pract 2016;35:123-6. 